\title{
A New Approach to the Scope of Contrastive Topics*
}

\author{
Beáta Gyuris \\ Research Institute for Linguistics, \\ Hungarian Academy of Sciences, Budapest \\ gyuris@nytud.hu
}

\begin{abstract}
This paper proposes a new strategy for accounting for the narrow scope readings of quantificational contrastive topics in Hungarian, which is based on a consideration of the types of questions that declaratives with such contrastive topics can be uttered as partial or complete congruent answers to. The meaning of the declaratives with contrastive topics will be represented with the help of the structured meaning approach to matching questions proposed in Krifka 2002 .
\end{abstract}

\section{The Phenomenon}

The aim of this paper is to propose a new strategy for accounting for the preference of quantificational expressions playing the role of contrastive topic (CT) in Hungarian for taking narrow scope with respect to a second quantificational expression following them.

In this paper (like in Gyuris 2002), contrastive topics will be defined on the basis of syntactic and prosodic criteria. Following É. Kiss 2002, we will assume that contrastive topics are maximal projections (as opposed to Büring 1997) situated in the Spec, TopP (topic) position of the sentence, and they bear a strong contrastive stress and a rising intonation, marked by '/ in the examples to follow. As it will be discussed in more detail below, contrastive topics are always followed by a constituent which bears a strong contrastive stress (eradicating stress, cf. Kálmán \& Nádasdy 1994) and a falling tone, marked by 'I' below.

The examples below show that as opposed to other preverbal operator positions of the Hungarian sentence (cf. (8) below), which can only host quantificational expressions with specific semantic properties (e.g.,

\footnotetext{
* I wish to thank Regine Eckardt, Cornelia Endriss, Andreas Haida, Hans-Martin Gärtner, László Kálmán, Manfred Krifka, as well as audiences at the Zentrum für Allgemeine Sprachwissenschaft (ZAS) in Berlin, Lund University, and the University of Amsterdam for discussions and criticism. I wish to thank the ZAS especially for hosting me and providing me with a stimulating environment during the time of my research grant from the Humboldt Foundation, which is hereby also gratefully acknowledged.
} 
monotonicity or distributive interpretation; see Szabolcsi 1997), the contrastive topic position is open to any quantificational expression. The examples shown in (1)-(3) have only one reading, in which the CT takes narrow scope with respect to the exhaustive focus, as in (1), or the universal DP following it, as in (2)-(3).

(1) [CT /Háromnál kevesebb könyvet] [FP \János olvasott el. $]^{1}$ three-than fewer book-acc John read VM

i. \#'There are fewer than three books such that all of them was read by John and no one else.' $\exists_{<3}>$ Focus

ii. 'It is John who read fewer than three books.' Focus $>\exists_{<3}$

(2) [CT /Legalább két lányt] [QP \minden fiú meglátogatott.] at least two girl-acc every boy VM-visited

i. \#'There are at least two girls who were visited by every boy.' $\exists_{2 \leq} \forall$

ii. 'Every boy has visited at least two girls.' $\forall \exists_{2 \leq}$

(3) $\left[\mathrm{CT}_{\mathrm{C}} /\right.$ Legalább két lány][QP $\backslash$ minden fiút meglátogatott.] at least two girl every boy-acc VM-visited

i. \#'There are at least two girls who visited every boy.' $\exists_{2 \leq} \forall$

ii. 'Every boy has been visited by at least two girls.' $\forall \exists_{2 \leq}$

Together, (2) and (3) also show that the availability of the narrow scope reading for the contrastive topic DP does not depend on its case.

Sentence (4) below illustrates the fact that certain sentences with quantificational $\mathrm{CT}$ s can also have a reading where the contrastive topic appears to take wide scope with respect to the quantifier/operator following it. I claim that in these cases the $\mathrm{CT}$ expression receives an e-type interpretation, and therefore there is no real scope interaction between the contrastive topic and the operator following it. (The CT expressions which give rise to the apparent wide-scope reading are identical to the ones which can appear as ordinary topics in the sentence.) The apparent wide-scope readings of CTs will, however, not concern us in the rest of the paper.

[CT /Két lány][QP \minden fiút meglátogatott.]
two girl every boy-acc

i. 'Two girls are such that they visited every boy.' $\exists_{2} \forall$

ii. 'Every boy has been visited by (at least) two girls.' $\forall \exists_{2}$

The next example illustrates scope reversal between a quantificational CT and negation, a type most often discussed in the literature with respect to German, for example. In this paper, however, we will not make any claims regarding such examples.

\footnotetext{
${ }^{1}$ In the examples, the contrastive topic constituents will be marked with the subscript CT.
} 


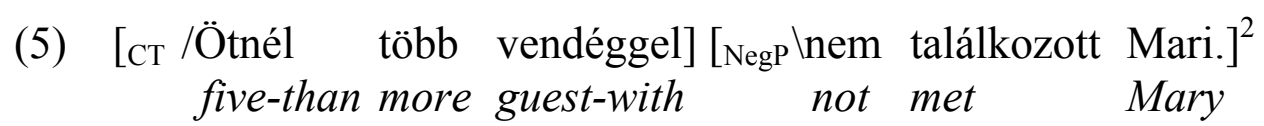

i. \#'There are more than five guests whom Mary did not meet' $\exists_{2} \neg$

ii. 'It is not true that Mary met more than five guests.' $\neg \exists_{2}$

The possibility, or sometimes the obligatoriness, of the narrow scope reading of contrastive topics is not specific to Hungarian. The following examples illustrate corresponding phenomena in German, investigated most recently by Jacobs (1997), Büring (1997), and Krifka (1998):

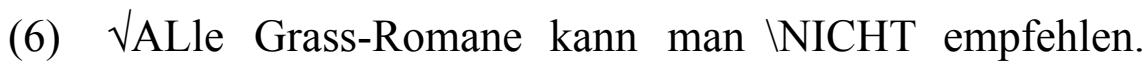
all Grass-novels can one not recommend

'It's not the case that all novels by Grass could be recommended.'

(Jacobs 1997)

(7) Mindestens /EIN Student hat JJEden Roman gelesen. at least one student-nom has every-acc novel read 'At least one student has read every novel.' $\forall(\exists), \exists(\forall)$

(Krifka 1998)

The reason why the Hungarian data illustrated above appear problematic is that they seem to contradict the so-called scope principle of generative grammar, according to which operators scope over the domain they ccommand, which is otherwise observed in visible syntax in Hungarian (É. Kiss 2002), at least as far as the preverbal operator positions of the Hungarian sentence are concerned. The surface structure of the Hungarian sentence assumed here, a simplified version of that proposed in É. Kiss 2002, is shown in (8) below:

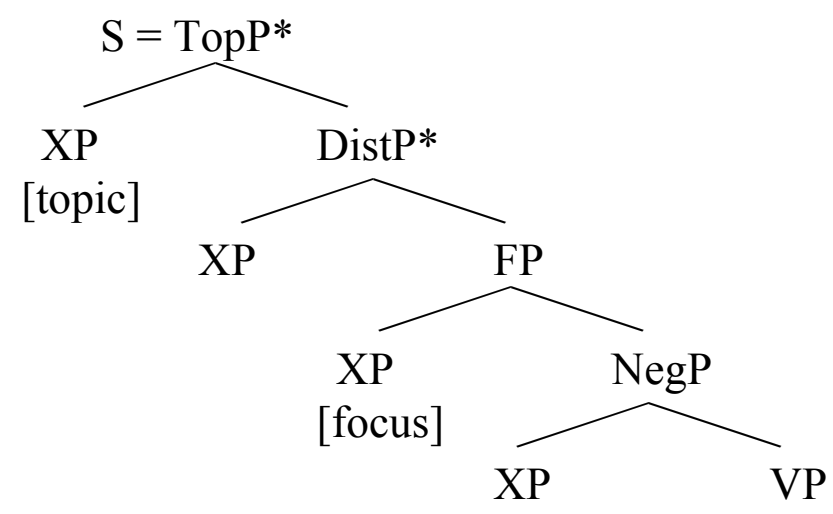

Sentence (9) below illustrates the workings of the scope principle with respect to quantificational expressions in the preverbal operator positions (Spec, DistP vs. Spec, FP). As the glosses show, the only available reading for this sentence

\footnotetext{
${ }^{2}$ Sentences (2)-(3) and (5), however, do have a reading where scope corresponds to linear order if the sentence-initial constituents are pronounced with a falling intonation pattern instead of the rise-fall.
} 
is the one where the quantificational expressions take scope according to their linear order:

(9) [DistP Mindkét süteményt] [FP kevés gyerek kóstolta meg.] all-two cake-acc few child tasted VM

i. 'For both cakes, it was few children that tasted them.' (É. Kiss 2002)

ii.\#'There are few children who tasted both cakes.'

Note that, as mentioned above, contrastive topics are assumed, following É. Kiss 2002, to be situated in the specifier position of one of the TopP projections, since they can both precede and follow ordinary topics in the sentence.

The structure of the rest of the paper is as follows. In section 2, some previous proposals to account for the German counterpart of the Hungarian phenomenon under discussion are reviewed, and the possibility of extending them to Hungarian is investigated. In section 3, the discourse functions of CTs are reviewed, with special reference to the questions they can be uttered as answers to. In section 4, a proposal accounting for the narrow scope reading of CTs in the structured meanings framework is presented. The paper closes with the conclusions in section 5.

\section{Some Previous Accounts for German}

\subsection{Büring 1997}

According to Büring (1997), sentences containing a CT expression capable of scope-taking and another operator following it are potentially ambiguous as to the scope of these operators in German. The availability of a particular reading is dependent on the availability of 'reasonable implicatures', which are due to the CT.

The above implicature is then formulated by him as follows. First, he associates with each sentence containing a CT a so-called CT-value, ${ }^{3}$ which is a set of sets of propositions. Each set consists of all the possible propositions which can be generated by replacing the denotation of the focus in the original proposition corresponding to the denotation of the sentence with the CT by one of its alternatives (including the focus denotation itself). The sets differ from each other in that in each of them, the contrastive topic denotation is

\footnotetext{
${ }^{3}$ Büring (1997) in fact uses the term Topic value for this concept, and the term Topic to refer to the constituents which are traditionally called contrastive topics in the literature (and this paper as well). In his later work, Büring 2003, he adopts the traditional terminology, however. Although in Büring 2003 he does not discuss the scope reversal effect, we will use his later terminology to discuss the proposals made in his earlier work for the sake of homogeneity.
} 
replaced by a different one of its possible alternatives (the set of which includes the contrastive topic denotation itself). The CT-values corresponding to the two potential readings in (10), for example, are illustrated in $(11 \mathrm{a}, \mathrm{b})$ :

(10) /ALlePolitiker sind INICHT korrupt. All politicians are not corrupt

i. 'It is not the case that all politicians are corrupt.' ii. \#'No politician is corrupt.' (= 'All politicians are such that they are not corrupt.')

(11) a. $[[(10 \mathrm{i})]]^{\mathrm{ct}}=\lambda P . \exists Q_{\langle e t,<e t\rangle>}\left[Q \in \mathrm{ALT}(\right.$ all $) \& P=\lambda p \cdot \exists \pi_{<t>}[\pi \in \mathrm{ALT}($ not $)$ $\& p=\pi Q$ (politicians)(corrupt)]]

b. $[[(10 \mathrm{ii})]]^{\mathrm{ct}}=\lambda P . \exists Q_{\langle e t,\langle e t, t\rangle\rangle}\left[Q \in \mathrm{ALT}(\mathbf{a l l}) \& P=\lambda p \cdot \exists \pi_{\langle t\rangle}[\pi \in \mathrm{ALT}(\right.$ not $)$ $\& p=Q(\operatorname{politicians})(\lambda x . \pi(\operatorname{corrupt}(x)))]]$

In view of the fact that sets of propositions correspond to questions in Hamblin's (1973) theory, the implicature associated with a sentence containing a $\mathrm{CT}$ is formulated by Büring as follows: there is an element $\mathrm{Q}$ in $[[\mathrm{A}]]^{\text {ct }}$ (CT-value of A) which is still under consideration (or: disputable) after uttering A. (Disputability of a question means that, given a common ground, there should be at least one element in the set of propositions corresponding to the question which is informative and non-absurd with respect to the common ground, i.e., not included in the common ground and not in contradiction with it.) The sets of questions corresponding to the sets of propositions in $(11 \mathrm{a}, \mathrm{b})$ are shown in (12a, b), respectively.

(12) a. \{Are all politicians corrupt?, Are most politicians corrupt?, Are some politicians corrupt?, Is one politician corrupt?, Are no politicians corrupt?...\}

b. \{As for all politicians, are they corrupt or not?, As for some politicians, are they corrupt or not?, As for one politician, is (s)he corrupt or not?...\}

Since the utterance of (10) on its (i) reading leaves the questions in (12a) except for the first one disputable, this reading will be available for the sentence. However, the utterance of the sentence on the (ii) reading would entail the answers to all of the questions in (12b), i.e., none of them will be left debatable, and therefore this reading will not be available for the sentence.

The problem with applying this theory to Hungarian, however, as pointed out also in Gyuris, to appear, is that there are sentences in Hungarian, like the ones in (2)-(3) and (5), whose 'wide-scope readings' would have to be available according to Büring's theory. For example, the set of questions corresponding to the topic value of (2) on its (i) reading are listed in (13): 
(13) \{Given a set of at least two girls, how many boys visited them?, Given a set of at least three girls, how many boys visited them?, Given a girl, how many boys visited her?...

Unfortunately, Büring does not discuss sentences with contrastive topics of the at least $n$ NP-type, and therefore does not discuss what alternatives would be introduced by the above NP. In any case, we could safely assume, I believe, that the denotation of exactly one NP will be an alternative of the denotation of at least two NP. In that case, however, the answer to the question, given a set of at least two girls, how many boys visited them, corresponding to (2i), does not entail an answer to the question, given exactly one girl, how many boys are such that they visited her.

\subsection{Jacobs 1997}

In Jacobs 1997, the sentence in (6) is considered an example of the construction-type I-topicalization (topicalization by intonation), whose defining characteristics include the reversal of the scope of operators with respect to their linear order.

Jacobs argues that the narrow scope of I-topics is due to an assertive or directive operator (Jacobs assumes that I-topicalization is only possible in assertive or directive sentences in German), introduced by the functional head spelling out the properties of this construction, which transforms the whole comment part of the sentence into a predicate, which then takes the topic part (i.e., the constituent bearing the fall-rise intonation contour, referred to by Jacobs as the root contour) as its argument. The semantic value of the sentence would then be derived as follows:

$$
\text { (14) }\left[\left[\operatorname{ASSERT}^{\mathrm{IT}}(\mathrm{TOP})(\mathrm{PRED})\right]\right]_{\text {prop }}=[[\mathrm{PRED}]]([[\mathrm{TOP}]])
$$

Jacobs (1997) differentiates the above construction from the construction referred to by him as I-specification, which involves a stressed indefinite determiner to be understood as specific, as in (15):

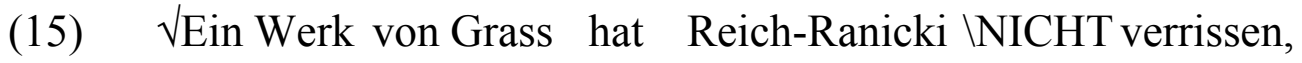
one work of Grass have Reich-Ranicki not pulled to pieces 'One work by Grass Reich-Ranicki did not criticize severely.'

a. nämlich die ,BLECHtrommel'.

namely the tin drum

'namely, The Tin Drum.'

b. ?aber MANche Werke HAT er verrissen.

but several works have he pulled to pieces

'but several works he did severely criticize.' 
Jacobs claims that the fact that (15) cannot be continued the way illustrated in (15b) indicates that (6) and (15) belong to different construction types. A potential problem with this way of reasoning is illustrated by a variant of (15) below, which in fact can have two interpretations. Since Jacobs only uses the indefinite determiner ein 'one' in his examples, which only gives rise to the type of reading illustrated in (15a), it is not evident from his account how he would handle examples like (16), which seem to be manifestations of both construction types: ${ }^{4}$

(16) $\sqrt{ }$ Zwei Werke von Grass hat Reich-Ranicki $\backslash$ NICHT verrissen. two works of Grasshave Reich-Ranicki not pulled to pieces

i. 'There are two works by Grass which Reich-Ranicki did not criticize severely.'

ii. 'It is not true that Reich-Ranicki criticized two works by Grass severely.'

Some further problems with Jacobs' account are pointed out by Molnár \& Rosengren (1996), which include, among others, the fact that CTs in Hungarian are not only possible in assertive/directive sentences, but also in questions, as illustrated in (17):

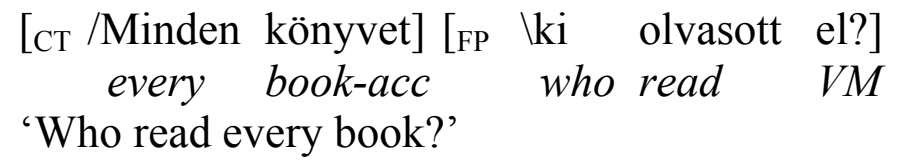

\subsection{Krifka 1998}

The account offered for the narrow scope reading of sentences like (7) above in Krifka 1998 is based on the following assumptions. On the one hand, it builds on the scope assignment principle proposed by Frey (1993) for German S-structure : 'If $\alpha, \beta$ are operators occurring in a sentence $S$, then $S$ has a reading in which $\alpha$ has scope over $\beta$ iff i) $\alpha$ c-commands $\beta$, or ii) $\alpha$ ccommands a trace of $\beta$.' On the other hand, it assumes that a clause-initial constituent carrying the rise in a rise fall contour is a 'focus in topic', i.e., a constituent moved from a preverbal position, where focus is assigned to it, into topic position (focus can be assigned prior to movement). ( $7^{\prime}$ ) below illustrates how the structure in (7) is derived on the basis of the above assumptions:

(7') $\left[\mathrm{CP}_{\mathrm{CP}}[\text { mindestens ein Student }]_{\mathrm{F}, 3}\left[\mathrm{C}_{\mathrm{C}}\right.\right.$, hat ${ }_{1}\left[[\text { jeden Roman }]_{\mathrm{F}, 2}\right.$

$\left[\mathrm{t}_{3}\left[\mathrm{t}_{2}\right.\right.$ [gelesen]]] $\left.\left.\left.\mathrm{t}_{1}\right]\right]\right]$

'At least one student has read every novel.' $\forall(\exists), \exists(\forall)$

\footnotetext{
${ }^{4}$ The explanation for the non-existence of reading (15b) in fact follows from Büring's theory.
} 
As pointed out in É. Kiss \& Gyuris 2003, however, none of these assumptions hold in Hungarian. First, the operators preposed into $\mathrm{A}^{\prime}$-positions dominating the VP, as illustrated in (8) above, originate from VP-internal positions, and thus they all c-command the traces of their clause-mates, which means that the relative scopes of the preverbal operators should be free — which, as discussed above, does not hold in Hungarian. Second, the movement of a contrastive topic through Spec, FP and then the filling of Spec, FP by another constituent would violate the strict cycle condition. Third, there are various types of constituents which can function as contrastive topics, but cannot occupy the Spec, FP position - for example, universal quantifiers, or existential quantifiers of the vala 'some' type.

Having discussed some of the existing accounts for the narrow scope readings of German contrastive topic quantifiers, and having established that none of them could be adopted to the Hungarian case, in what follows I will propose an account of the narrow scope of Hungarian contrastive topics which is based on the investigation of the discourses where such constituents can appear.

\section{Contrastive Topics in the Discourse}

\subsection{Basic Assumptions}

The account I would like to offer for the narrow scope readings of contrastive topics is based on a consideration of the discourse functions of the sentences where these constituents can appear. Kálmán (1985) observes, for example, that contrastive topics can only appear in non-neutral or corrective sentences, where such constituents are followed by a second constituent with a strong contrastive stress, or eradicating stress. The above requirement entails, I believe, that contrastive topics cannot appear in sentences uttered 'out of the blue', or as answers to questions of the 'What happened?' type, which is in fact confirmed by the data.

Several accounts of Hungarian, including Szabolcsi 1981b, Kenesei 1989, Molnár 1998, as well as of other languages, including Lambrecht 1994, Vallduví \& Engdahl 1996, Lee 1999, von Fintel 1994, and Büring 1997, emphasize the need for contrastive topics to be followed by semantic focus, which is assumed to carry the second intonational peak of the sentence. As the data in (1)-(5) can illustrate, the constituent with the strong contrastive (eradicating) stress following the contrastive topic does not have to be identical to the constituent which is normally referred to as the focus of the sentence in the current generative literature on Hungarian, i.e., the one sitting in the preverbal focus position (spec, FP). In order to distinguish the constituent with the eradicating stress following the contrastive topic from the 
syntactic focus, the former will be referred to here, following the practice of Gyuris 2002, as the associate of the contrastive topic. The associates of the contrastive topic will be assumed to be maximal projections here, just like the contrastive topics themselves.

The phenomenon that contrastive topics do not normally figure as initial sentences of discourses is due to the fact that they provide partial answers to questions under consideration in the discourse (see Roberts 1996). This idea has been around for some time in the literature. Szabolcsi (1981a) claims, for example, that the presence of a contrastive topic in a discourse indicates that there are things other than the one referred to by the contrastive topic about which the same question could be asked, and it is possible that the answer to those questions would be different. Kálmán \& Rádai (1998) claim that the presence of the contrastive topic indicates that the declarative does not provide an exhaustive answer to a question, as opposed to answers containing only a focus. Büring (2003) argues that the presence of a contrastive topic in a sentence indicates that a question under discussion in a discourse is not answered in one step, but divided into subquestions, i.e., by applying a strategy to answer the question. The declarative with the contrastive topic would then be answering one subquestion of the original one.

On the basis of these discussions I will argue in what follows that for any Hungarian sentence with a contrastive topic, it is possible to determine two different questions. The first among these is the question which it provides a congruent answer to, where the latter term is used in the sense proposed in von Stechow 1991, according to which an answer is a congruent answer to a question if the alternatives introduced by the question are the same as the alternatives determined by the answer. As an illustration, compare $(18 \mathrm{~b}, \mathrm{c})$ as answers to (18a) (von Stechow 1991:68):

(18) a. Does Ede want tea or does he want coffee?

b. *Ede wants tea.

c. Ede wants coffee.

Since (18a) determines the alternatives wants(Ede,x), but (18b) determines alternatives of the form wants $(x$, tea $)$, the latter does not count as a congruent answer to the former, in contrast to (18c). In other words, in congruent question-answer sequences, the denotation of the constituent which would appear in a term answer is from the domain determined by the question word. In accordance with É. Kiss 2002, congruent answers in Hungarian will also be assumed to be exhaustive or complete (see Groenendijk \& Stokhof 1990).

The second question to be associated with declaratives containing a contrastive topic will be the one which the latter provides a partial answer to (Groenendijk \& Stokhof 1990), or, using the terminology of Büring 2003, takes part in the strategy associated with it. These latter questions are multiple 
wh-questions, to be discussed below. In view of the fact that all sentences with a contrastive topic in Hungarian can be associated with sentences of the above two types, I will derive the interpretation of sentences with contrastive topics from that of questions. In what follows, I provide some data and discussion about the questions which declaratives with contrastive topics provide complete versus partial answers to, classified according to the type of the associate of the contrastive topic.

\subsection{Declaratives with CTs as Complete Congruent Answers}

As the data below indicate, the sentences in which contrastive topics appear in Hungarian fall into two types. On the one hand, as discussed more thoroughly in section 3.2.1, the contrastive topic can be followed by an associate which occupies the syntactic focus position or a quantifier position in the preverbal field. On the other hand, the associate role can be played by a verum focus or a negative particle, as discussed in section 3.2.2. As mentioned earlier, in this paper we will concentrate on the interpretation of sentences of the first type. For the sake of completeness, however, I consider it important to provide at least some data related to the second group as well. The declaratives with the contrastive topics below are shown together with the question which they provide a complete congruent answer to. Note that they do not always appear to form natural discourses with the latter, since in most discourses the declaratives with contrastive topics are preceded by questions which they provide partial answers to. (The questions which they provide complete answers to would be viewed as subquestions to these, as proposed in Büring 2003.)

\subsubsection{Type 1: Focus or Quantifier (in Spec, DistP) as Associate}

Declaratives where the associate of the contrastive topic is situated in the Spec, FP or the Spec, QP position can occur in complete congruent answers to wh-questions. The sentence in (1) above, as well as (19), are examples of this construction:

$$
\begin{aligned}
& \text { [Cт /Minden könyvet] [FP lkét diák olvasott el.] } \\
& \text { every book-acc two student read VM } \\
& \text { i. \#'For every book it was two students who read it.' } \\
& \text { ii. 'It was two students who read every book.' }
\end{aligned}
$$

The questions to which (19) provides a complete congruent answer are shown in (20), whereas the ones corresponding to (1) are illustrated in (21). Note that whereas in the (a) questions the constituent corresponding to the $\mathrm{CT}$ in the answer appears in postverbal position, in the (b) questions it functions as a contrastive topic: 
(20) a. [FP Ki olvasott el minden könyvet? ] who read VM every book-acc

'Who read every book?'

b. [CT/Minden könyvet] [ [FP $\backslash \mathrm{ki}$ olvasott el?] every book-acc who read VM

'Who read every book?'

(21) a. [FP Ki olvasott el háromnál KEvesebb könyvet?] who read VM three-than fewer book-acc

'Who read fewer than three books?'

b. [CT/Háromnál kevesebb könyvet] [FP $\backslash \mathrm{ki}$ olvasott el?] three-than fewer book-acc who read VM

'Who read fewer than three books?'

(2) and (3) above illustrate a case where the associate is situated in Spec, DistP position. Note that this option is only available for universal NPs and most NPs (in the majority of NP-reading), which are excluded from the focus position on syntactic grounds. The questions associated with (2) are shown in (22):

(22) a. [ ${ }_{\mathrm{FP}} \mathrm{Ki}$ látogatott meg legalább két lányt?] who visited VM at least two girl-acc

'Who visited at least two girls?'

b. [CT /Legalább két lányt] [FP $\backslash \mathrm{ki}$ átogatott meg?] at least two girl-acc who visited VM 'Who visited at least two girls?'

Note that the questions in (21)-(22) can only have one possible answer (which exhaustively specifies the persons who have the property of having read fewer than three books, for (21), or the persons who have the property of having visited at least two girls, for (22)). In other words, there are no choice readings for (21) and (22) (Szabolcsi \& Zwarts 1993).

\subsubsection{Type 2: Verum or Falsum Focus as Associate}

In the declarative in (23) below, as well as in the negative sentence in (5) above, the associate of the contrastive topic is a verum (VP) focus, and its negation, respectively. These sentences provide complete congruent answers to yes-no questions, the alternatives introduced by which are a proposition and its negation. The declaratives with the contrastive topic then choose one of these alternatives. (24) shows the yes-no questions associated with (5): 
(23) $[\mathrm{cT} / \text { Öt vendéggel] [vP \találkozott Mari. }]^{5}$ five guest-with met Mary

i. 'There are five guests whom Mary met.'

ii. 'There WAS an event of Mary meeting five guests.'

(24) a. Találkozott Mari ötnél több vendéggel? met Mary five-than more guest-with 'Has Mary met more than five guests?'

b. [CT/Ötnél több vendéggel] [vp Italálkozott Mari?] five-than more guest-with met Mary 'Has Mary met more than five guests?'

Note that the verb playing the role of the associate does not necessarily denote a verum focus, but it can also be interpreted as contrastive focus when it is contrasted with other verb denotations, and therefore does not answer a yes/no question but a $w h$-question. For example, (23) can also be assumed to serve as a congruent answer to a wh-question of the type What did Mary do to five guests? As mentioned earlier, declaratives where the contrastive topic is followed by a verum or a falsum focus will not be discussed further in this paper.

\subsection{Declaratives with CTs as Partial Answers to Matching Questions}

As mentioned above, declaratives with a contrastive topic and an associate situated in the Spec, FP or Spec, DistP position provide partial answers to multiple $w h$-questions with fronted $w h$-phrases. In this section we consider the issue of how the type of multiple wh-question can be predicted from the properties of the declarative with the contrastive topic.

\subsubsection{Multiple $\boldsymbol{W h}$-questions with Fronted $\boldsymbol{W h}$-phrases in Hungarian}

É. Kiss (2002) argues that multiple wh-questions with fronted wh-words like the ones in (25) expect a list answer which for each member of the domain of the first question word exhaustively specifies the answer corresponding to the second question word: ${ }^{6}$

\footnotetext{
${ }^{5}$ We follow É. Kiss 2002, according to which the verb does not move to the Spec, FP position when focused.

${ }^{6}$ In multiple questions requiring a singular answer, one wh-word moves to Spec, FP, while the other remains in situ:
}
(i) [FP KI verekedett [FP kivel?]] who fought who-with
(É. Kiss 2002)
'Who fought with whom?'


(25)
a. [DistP Ki [FP MELYIK AJÁNDÉKOT választotta?] who which present-acc chose
'Who chose which present?' (For each relevant person, provide an exhaustive list of the presents he/she chose.)
b. [DistP Melyik ajándékot[FP KI választotta?] which present-acc who chose
'Which present was chosen by whom?' (For each relevant present, provide an exhaustive list of the persons who chose it.)

Thus, the answers to $(25 \mathrm{a}, \mathrm{b})$ are not interchangeable. With respect to multiple wh-questions in English like (26) below, Büring (2003) claims that they can be answered in two ways, by considering the relevant persons one-by-one, and providing for each of them what they ate, or by considering the relevant types of food, and providing for each of them the person(s) who ate them.

(26) Who ate what?

Kuno (1982) shares the view of Büring (2003), by adding that there are marked and unmarked options for answering a multiple wh-question in English; whereas Krifka (2002) is of the opinion that there is always only one way of answering such a question (provided the question presupposes a list answer and does not only expect one pair as an answer, i.e., it is not a conjoined question).

Returning to the Hungarian case, it is proposed by É. Kiss (2002) that the last question word in a multiple wh-question like $(25 \mathrm{a}, \mathrm{b})$ is situated in Spec, FP, whereas the ones preceding it are in Spec, DistP. She argues that the question words in Spec, DistP are discourse-linked and appear to function as universal quantifiers, i.e., a complete answer to the question must provide for each element in the domain of these question words a value chosen from the domain of the last question word.

Note that the multiple $w h$-questions discussed above are the only possible means to express a 'family of questions' reading in Hungarian - that is, quantifiers never scope over WH in Hungarian. (É. Kiss 1991; Szabolcsi 1983). The following sentence, for example, where the universal quantifier precedes the question word, must be pronounced with a contrastive topic intonation on the latter, which indicates that it falls into the scope of the question word:

$$
\begin{aligned}
& \text { [TopP /Mindenki [FP \MELYIK AJÁNDÉKOT választotta?] } \\
& \text { everybody which present-acc chose } \\
& \text { 'What is the present(s) chosen by everybody?' }
\end{aligned}
$$

To sum up, the Hungarian multiple constituent questions illustrated above satisfy the following conditions on matching questions formulated in Krifka 2002. They presuppose a list answer; one of the question words, usually the 
first one, should be linked to a contextually given set (Comorovski 1996), i.e., be D-linked; a matching question in which one wh-constituent is D-linked is assumed to be 'about' the antecedent set of this constituent; and they usually presuppose that every element in the set denoted by the D-linked constituent is part of one answer in the answer list.

\subsubsection{Contrastive Topics Surfacing in Answers to Matching Questions in Hungarian}

In this section we consider the conditions under which contrastive topics can appear as (partial) answers to matching questions in Hungarian. The first case is illustrated in (28), uttered as an answer to (25a), where the domain of the first question word contains individuals.

(28) [CT /Mari] [FP a könyvet választotta].

Mary the book-acc chose

'As for Mary, she chose the book.'

(28) provides a partial answer to (25a), since it is normally presupposed in the case of matching questions that the domain of the first question word consists of more than one element (Krifka 2002). Since it is not a complete answer to (25a), the constituent corresponding to the first question word must be pronounced with the contrastive intonation. The above sentence thus contrasts with (29), lacking a CT, which, provided that the set of relevant persons has two elements, can be considered a complete answer to (25a):

[TopPMari a könyvet], [TopP Peti a gitárt választotta.]
Mary the book-acc Peti the guitar-acc chose
'Mary chose the book and Pete the guitar.'

The second case is illustrated by (30b), uttered as an answer to (30a):
(30) a. Hány könyvet ki olvasott el? ${ }^{7}$ how many book-acc who read VM
'How many books were read by whom?'
b. [CT/Minden könyvet] [FP \Mari és Peti ], [CT/legalább kétkönyvet] every book-acc MaryandPete at least twobook-acc [DistP Iminden diák elolvasott.] every student VM-read

'As for every book, that many was read by Mary and Pete, as for at least two books, that many was read by every student.'

\footnotetext{
${ }^{7}$ This question can have another reading as well, in which it asks about a given set of books who read them, and the answer is expected to provide for each subset of this set the names of people who read it.
} 
Note that the domain of the first question word in (30a) does not consist of individuals but of quantities. This means that in (30b), the set of books read by Mary and Pete and the books read by everybody do not have to be disjunct. (Thus, the contrastive topics in (30b) belong to the category referred to by Eckardt (2004) as denotational topics). Since there can be infinitely many ways of characterizing quantities of books, asking a question like (30a) only makes sense if the relevant quantities are somehow fixed in the context beforehand. In answers to matching questions where the domain of the first question word does not contain individuals, the part of the answer corresponding to the first question word must always be pronounced with a contrastive topic intonation. The reason for this requirement could be, for example, that since quantities can be characterized in multiple ways, each answer would count as a partial one.

(31) illustrates one more property of the answers to matching questions formulated with the help of contrastive topics, also observed in van Hoof 2000 and Eckardt 2004 for German. Since each part of the list answer is assumed to be exhaustive with respect to the last question word, the relation between the denotations of the possible pairs appearing in a pair-list answer must be a function. In other words, (28) cannot be continued with (31):

(31) [ $_{\mathrm{CT}} /$ Mari] [DistP a labdát is választotta]. Mary the ball-acc also chose

'As for Mary, she also chose the ball.'

In this section I have argued for the existence of a systematic relation between declaratives with contrastive topics and questions to which they provide a complete congruent answer or a partial answer, respectively; and claimed that for any declarative with a contrastive topic it is possible to determine two questions which stand in the above relations to it. This close relation between declaratives with contrastive topics and questions indicates that we might get closer to providing an interpretation of the former by using semantic theories proposed for the latter. This is the task we turn to in the next section.

\section{Towards a Formal Treatment in terms of Structured Meanings}

\subsection{The Structured Meaning Approach to Matching Questions (Krifka 2002)}

According to the structured meaning approach to questions (e.g., von Stechow 1991; von Stechow \& Zimmerman 1984; for further references see Krifka 2002), question meanings are functions that, when applied to the meaning of 
the answer, yield a proposition (Krifka 2002: 288). (32) below (from Krifka 2002) illustrates how the meanings of questions and their answers can be represented in this framework:
A: Who read Die Kinder der Finsternis? $\quad<\lambda \mathrm{x}[\operatorname{READ}(\mathrm{KF})(\mathrm{x})]$, PERSON $>$
B: Mary. $\mathrm{M}$
Question applied to answer:

$$
\begin{aligned}
& \lambda x[\operatorname{READ}(\mathrm{KF})(\mathrm{x})](\mathrm{M}) \\
= & \operatorname{READ}(\mathrm{KF})(\mathrm{M})
\end{aligned}
$$

In (32), the meaning of the question is represented as a pair, whose first element is the function standing for the question, referred to as the background of the question, and the second the domain from where the value of $\mathrm{x}$ must come from, referred to as its restriction.

As argued by Krifka, the structured meaning framework for questions fits well with the structured meaning approach to focus (Cresswell \& von Stechow 1982; Jacobs 1983; Krifka 1991; von Stechow 1981, 1991), because the two together provide an appropriate way to characterize congruent question-answer pairs.

According to the structured meaning approach to focus, the meaning of an expression is split into a background part and a focus part, $<\mathrm{B}, \mathrm{F}>$. The background part is of a semantic type that can be applied to the focus. After carrying out this functional application we arrive at the ordinary meaning of the expression. (33) illustrates how the meaning assigned to a sentence in this framework varies with the choice of the focus.

(33) a. [Máry $]_{\mathrm{F}}$ read Die Kinder der Finsternis. $\quad<\lambda \mathrm{x}[\mathrm{READ}(\mathrm{KF})(\mathrm{x})], \mathrm{M}>$

b. Mary read [Die Kinder der Fínsternis. $]_{\mathrm{F}} \quad<\lambda \mathrm{x}[\mathrm{READ}(\mathrm{X})(\mathrm{M})], \mathrm{KF}>$

In the structured meaning framework, the congruence of questions and answers can then be defined in the following way: the backgrounds of the question and the answer must be the same, and the focus of the answer must be an element of the restriction of the question. Note that, according to this theory, the interpretation of the focus is not exhaustive. (Exhaustivity of an answer is indicated by focus-sensitive operators like only, as discussed in Krifka 1991.)

Having discussed some of the basic assumptions of the structured meaning approach to representing the meaning of questions and of expressions containing a focus, we turn now to the issue of how matching questions can be represented in this framework. In view of the properties of matching questions discussed above (the domain of the first question word is assumed to contain more than one element, the question expects that for each element in the domain of the first question word a value from the domain of the second question word is given, etc.), Krifka (2002) argues that matching questions in 
fact ask for a function, i.e., they should be viewed as functions having functions as arguments. (34) below first shows a standard way of representing the meaning of a matching question in the structured meaning framework in terms of a function having pairs consisting of a person and a thing as argument.

(34) Who read what?

$$
<\lambda<\mathrm{x}, \mathrm{y}>[\operatorname{READ}(\mathrm{y})(\mathrm{x})], \text { PERSON } \times \text { THING }>
$$

Note that with respect to (34) it is presupposed that each person read only one thing (Manfred Krifka, personal communication), which allows the formula on the right to be viewed as a function. The following operator is introduced by Krifka (2002) to transform representations of questions in terms of functions with pair arguments into representations in terms of functions with function arguments:

(35) a. $\quad \mathrm{FUN}(\mathrm{R})=\lambda \mathrm{f} \forall \mathrm{x}[\mathrm{x} \in \mathrm{DOM}(\mathrm{f}) \rightarrow \mathrm{R}(<\mathrm{x}, \mathrm{f}(\mathrm{x})>)]$, the set of functions $f$ such that every $x$ in the domain of $f$ stands in R-relation to $\mathrm{f}(\mathrm{x})$

b. $F \mathrm{FN}^{\prime}(\mathrm{A} \times \mathrm{B})=$ the set of functions from $\mathrm{A}$ to $\mathrm{B}$

As a result of applying the operator in (35a) to the representation on the right in (34), we get the one in (36) as the meaning of the question in (34):

(36) $<$ FUN $\left(\lambda<\mathrm{x}, \mathrm{y}>[\operatorname{READ}(\mathrm{y})(\mathrm{x})], \mathrm{FUN}^{\prime}(\right.$ PERSON $\times$ THING $)>$, where $\mathrm{FUN}(\lambda<\mathrm{x}, \mathrm{y}>[\operatorname{READ}(\mathrm{y})(\mathrm{x})])=\lambda \mathrm{f} \forall \mathrm{x}[\mathrm{x} \in \mathrm{DOM}(\mathrm{f}) \rightarrow \operatorname{READ}(\mathrm{f}(\mathrm{x}))(\mathrm{x})]$, the set of functions $f$ such that every $x$ in the domain of $f$ read $f(x)$, and FUN' (PERSONXTHING)=the set of functions from PERSON to THING.

The answer to the question in (34) then specifies a function by enumeration:

(37) Mari Die Kinder der Finsternis, and John Das Totenschiff.

$\mathrm{f:} \quad\{\mathrm{M}, \mathrm{J}\} \rightarrow\{\mathrm{KF}, \mathrm{TS}\}$

$\mathrm{M} \rightarrow \mathrm{KF}$

$\mathrm{J} \rightarrow \mathrm{TS}$

In this section, I provided an overview of the structured meaning approach to questions in general, and to matching questions in particular. Since multiple wh-questions with fronted wh-phrases in Hungarian are matching questions and the declaratives with CTs under investigation are partial answers to these questions, the approach to the interpretation of matching questions in Krifka 2002 will be used to derive the denotations of the latter in the sections to follow. 


\subsection{Applying the Structured Meaning Approach to Declaratives with Contrastive Topics in Hungarian}

As discussed above, declaratives with contrastive topics in Hungarian (where the associate role is played by an expression in Spec, FP or Spec, QP) provide partial answers to matching questions and complete answers to singular whquestions, the type of both of which is predictable from the declarative in question. Therefore, the interpretation of such declaratives will be generated in a way which reflects their close connection to the above types of questions.

On the one hand, as partial answers to matching questions, declaratives with CTs will be argued to make reference to functions taking functions as arguments, which figure in the representation of the meaning of matching questions, e.g., (36) above. On the other hand, as complete congruent answers to singular $w h$-questions, they will be claimed to indicate that the property corresponding to the background part of the question holds only of the denotation of the associate.

Note, however, that the desired interpretations for sentences like (1)-(5) do not automatically follow from the structured meaning approach. A crucial aspect of deriving the preferred interpretations involves making reference to the kinds of questions they can provide partial or complete answers to.

\subsubsection{Extending the Approach to Questions with Domains other than the Domain of Individuals}

Ultimately, we will provide a meaning representation for sentence (1) above, repeated here in (38):

(38) [Cт /Háromnál kevesebb könyvet] [FP \Jánosolvasott el.] three-than fewer book-acc John read VM

i. \#'There are fewer than three books such that all of them was read by John and no one else.' $\exists_{<3}>$ Focus

ii. 'It is John who read fewer than three books.' Focus $>\exists_{<3}$

I claim that a sentence like (38) above serves as a partial answer to a matching question like (30a) above, repeated here as (39), where the domain of the first question word contains properties referring to quantities (the number of atomic parts of a sum individual): ${ }^{8}$

(39) Hány könyvet ki olvasott el?

How many book-acc who read VM

'How many books were read by whom?'

\footnotetext{
${ }^{8}$ Remember that such questions cannot be answered in a manner other than using contrastive topics to refer to elements of the domain of the first question word.
} 
Since Krifka (2002) does not discuss matching questions with domains other than that of individuals or things, the first thing to do, if we want to connect the meaning of (38) to that of (39), is to provide a representation of the meaning of (39), and more generally, to provide a strategy for handling questions in this framework with non-individual domains. I propose that a representation for (39) satisfying the above requirements would be as shown below:

$$
\begin{aligned}
& \text { (40) }<\lambda \mathrm{f} \forall \mathrm{P}\left[\mathrm{P} \in \mathrm{DOM}(\mathrm{f}) \rightarrow \forall \mathrm{y}\left(\mathrm{y}=\left\lfloor\left\{\mathrm{z} \mid \operatorname{READ}(\mathrm{z})(\mathrm{f}(\mathrm{P})) \wedge^{*} \mathrm{BOOK}(\mathrm{z})\right\} \rightarrow \mathrm{P}(\mathrm{y})\right)\right],\right. \\
& \mathrm{FUN}^{\prime}\left(\mathbf{P} \times{ }^{*} \text { PERSON }\right)>\text {, } \\
& \text { where } \mathbf{P}=\left\{\lambda \mathrm{x}[\#(\mathrm{x})] \in \mathrm{N} \mid \mathrm{N} \subseteq \mathbf{N}_{\mathbf{0}}\right\} \text {, and } \mathrm{f}: \mathbf{P} \rightarrow{ }^{*} \text { PERSON }
\end{aligned}
$$

(40) states that the meaning of the question in (38) is a function with an argument having the type of a function. The domain of this function is a set of properties referring to a quantity (number of atomic parts of a sum individual). By representing this quantity as a subset of natural numbers, it becomes possible to handle the meanings of expressions like fewer than 3, between 5 and 10, an even number of, etc., in a parallel way. The value of this function at an argument is identical to the person for whom the sum of books he/she read has the property specified by the argument. Summation is necessary, since if a person read six books, then he/she also read five, four, etc. books, but in this case we do not expect that he/she would be the value associated with arguments denoted by fewer than 3, between one and four, etc. In view of the fact that there are infinitely many ways of characterizing quantities of books, it is important to note that the relevant properties (having a particular number of atomic parts where the number is taken from a subset of the set of natural numbers including zero, i.e., $\left.\mathbf{N}_{\mathbf{0}}\right)^{9}$ must be provided by the context. Note that according to the above view, if John did not read any books, he would also be able to surface as a value of the function at arguments which correspond to quantities determined by subsets of $\mathbf{N}_{\mathbf{0}}$ including the zero element, which is a welcome result. In this case, y equals the empty group (see Bonomi \& Casalegno 1993). The above representation, however, does not account for one thing: it does not allow answers like (41) to (39) in a case where John and Mary read different books:

(41) [CT/Háromnál kevesebb könyvet] [FP \János és Mari olvasott el.] three-than fewer book-acc John and Maryread VM 'It was John and Mary who read fewer than three books.'

In order to overcome the above difficulty, I propose that the meaning of (39) should instead be represented as in (42):

\footnotetext{
${ }^{9}$ This method of representing the relevant properties was suggested by Manfred Krifka (personal communication).
} 
(42)

$$
\begin{aligned}
& <\lambda \mathrm{f} \forall \mathrm{P}[\mathrm{P} \in \operatorname{DOM}(\mathrm{f}) \rightarrow \mathrm{f}(\mathrm{P})=\bigsqcup\{\mathrm{x} \mid \forall \mathrm{y}(\mathrm{y}=\mathrm{L}\rfloor\{\mathrm{z} \mid \operatorname{READ}(\mathrm{z})(\mathrm{x}) \wedge \\
& \left.\left.\left.\left.{ }^{*} \operatorname{BOOK}(\mathrm{z})\right\} \rightarrow \mathrm{P}(\mathrm{y})\right)\right\}\right], \\
& \mathrm{FUN}\left(\mathbf{P} \times{ }^{*} \operatorname{PERSON}\right)> \\
& \text { where } \mathbf{P}=\left\{\lambda \mathrm{x}[\#(\mathrm{x}) \in \mathrm{N}] \mid \mathrm{N} \subseteq \mathbf{N}_{\mathbf{0}}\right\}, \text { and } \mathrm{f:} \mathbf{P} \rightarrow{ }^{*} \operatorname{PERSON}
\end{aligned}
$$

(42) indicates that the value of the function at an argument equals the sum of individuals for whom it holds that the sum of books they read has the property corresponding to the argument.

Having considered the interpretation of matching questions where the domain of a question word does not include individuals, in the next section we turn to singular wh-questions which can be viewed as subquestions of the latter, and to which declaratives with $\mathrm{CT}$ of the type under consideration provide complete congruent answers.

\subsubsection{Extending the Approach to Subquestions of Matching Questions}

The idea we will pursue is this: declaratives with contrastive topics can surface as partial answers to matching questions. If in these matching questions the first $w h$-word is replaced by the contrastive topic in the declarative (also a contrastive topic in the question), we obtain a singular wh-question to which the declarative with the $\mathrm{CT}$ provides a complete congruent answer - the denotation of the associate of the $\mathrm{CT}$ in the declarative is of the same semantic type as the restriction of the question. For example, (43) below is a question which is generated from (39) in the above manner, and for which (38) provides a complete congruent answer:

$$
\begin{aligned}
& \text { [CT /Háromnál kevesebb könyvet] [FP } \text { ki olvasott el?] } \\
& \text { three-than fewer book-acc who read pfx } \\
& \text { 'Who read fewer than three books?' }
\end{aligned}
$$

A complete congruent answer for (43) is one which gives the name of the person for whom the property of having read fewer than three books holds. I believe that the representation of the meaning of (43) should make reference to the fact that this sentence is a subquestion of one which asks for a function, and that the denotation of the contrastive topic in this question corresponds to one argument of the function. Similarly, by incorporating such a function into the meaning of declaratives with contrastive topics, we can account for the fact that a sentence with a CT cannot introduce an alternative statement in which the same contrastive topic expression is followed by a different associate. Accordingly, I propose that the meaning of (43) should be represented as in (44): 


$$
\begin{aligned}
& <\lambda \mathrm{v} \exists \mathrm{f}[\lambda \mathrm{x}[\mathrm{H}(\mathrm{x})<3] \in \mathrm{DOM}(\mathrm{f}) \wedge \mathrm{v}=\mathrm{f}(\lambda \mathrm{x}[\#(\mathrm{x})<3]) \wedge \\
& \wedge \mathrm{v}=\lfloor\rfloor\{\mathrm{x} \mid \forall \mathrm{y}(\mathrm{y}=\lfloor\rfloor\{\mathrm{z} \mid \operatorname{READ}(\mathrm{z})(\mathrm{x}) \wedge * \operatorname{BOOK}(\mathrm{z})\} \rightarrow \#(\mathrm{y})<3)\}], \\
& * \text { PERSON }, \\
& \text { where } \mathbf{P}=\left\{\lambda \mathrm{x}[\#(\mathrm{x}) \in \mathrm{N}] \mid \mathrm{N} \subseteq \mathbf{N}_{\mathbf{0}}\right\}, \text { and } \mathrm{f}: \mathbf{P} \rightarrow * \text { PERSON }
\end{aligned}
$$

The above formula assigns a pair to (43) whose first member is a function with a domain consisting of persons, including sums of atomic persons as well, and whose second member is the set of (plural) persons. The value of the function at an argument equals the sum of persons with the property that the sum of books which they read has fewer than three atomic parts. The formula also states that there is a function $f$ whose domain includes the property of consisting of fewer than three atomic parts, and that the answer to the question varies with respect to the arguments of the function. I will assume that a question like (43) presupposes that there is an individual in the range of the function corresponding to the question who read books, and therefore that the protasis of the implication in the first member of the pair of (44) is true. If this presupposition is not satisfied then we are facing the case where no book was read by the person, and therefore, y equals the empty group (see Bonomi \& Casalegno 1993), which, naturally, has fewer than three atomic parts.

(45) below then shows the representation assigned to a complete congruent answer for (43), namely, (38):

$$
\begin{aligned}
& <\lambda \mathrm{v} \exists[\mathrm{f}[\lambda \mathrm{x}[\#(\mathrm{x})<3] \in \mathrm{DOM}(\mathrm{f}) \wedge \mathrm{v}=\mathrm{f}(\lambda \mathrm{x}[\#(\mathrm{x})<3]) \wedge \\
& \left.\wedge \mathrm{v}=\lfloor\rfloor\left\{\mathrm{x} \mid \forall \mathrm{y}\left(\mathrm{y}=\lfloor\rfloor\left\{\mathrm{z} \mid \operatorname{READ}(\mathrm{z})(\mathrm{x}) \wedge{ }^{*} \operatorname{BOOK}(\mathrm{z})\right\} \rightarrow \#(\mathrm{y})<3\right)\right\}\right], \\
& \mathrm{J}>, \\
& \text { where } \mathbf{P}=\left\{\lambda \mathrm{x}[\#(\mathrm{x}) \in \mathrm{N}] \mid \mathrm{N} \subseteq \mathbf{N}_{\mathbf{0}}\right\}, \text { and } \mathrm{f}: \mathbf{P} \rightarrow{ }^{*} \text { PERSON }
\end{aligned}
$$

From (45) the exhaustivity of the focus in (38) follows without any additional requirement, since John can only be the sum of the set of individuals with the property of having read one book if the set of such individuals contains only John. Note that the above formalism correctly accounts for the fact that the focused expression appears to take wide scope, i.e., the contrastive topic expression cannot be interpreted as referring to specific books which are fewer than three in number.

The variant of (38) shown below, however, can have two readings:

$$
\begin{aligned}
& \text { (46)[ст /Öt könyvet] [FP \Mari olvasott el.] } \\
& \text { five book-acc Mary read pfx } \\
& \text { i. 'It is Mary who read five books.' } \\
& \text { ii. 'There are five books such that for each of them it holds that it is } \\
& \text { Mary who read it.' }
\end{aligned}
$$

I believe that the availability of both a wide and a narrow scope reading for the CT in (46), as well as in (4) above, is due to the fact that the sentences can be uttered as partial answers to wh-questions (like the one in (39)) where the 
domain of the question word corresponding to the contrastive topic includes properties, as well as to those where the domain of the above question word includes individuals. For example, (46) can be uttered as a partial answer to a question like Which books were read by whom?

\section{Conclusions}

In this paper, I proposed a new way of handling the narrow scope readings of quantificational contrastive topics in Hungarian. I concentrated on sentences where the contrastive topic is followed by a quantificational expression in one of the preverbal operator positions of the Hungarian sentence. I argued that such sentences serve as partial answers to multiple wh-questions with fronted wh-words, which have the properties of matching questions, and as complete congruent answers to singular $w h$-questions. I claimed that the scope properties of quantificational contrastive topics depend on the types of the elements in the domain of the question word they correspond to when they constitute a partial answer to a matching question. I represented the denotations of declaratives as well as the two questions associated with them in the above manner in terms of the structured meaning framework to matching questions proposed in Krifka 2002.

\section{References}

Bonomi, Andrea and Paolo Casalegno. 1993. ONLY - Association with Focus in Event Semantics. Natural Language Semantics 2: 1-45.

Büring, Daniel. 1997. The Meaning of Topic and Focus. The 59th Street Bridge Accent. Routledge, London/New York.

Büring, Daniel. 2003. On D-Trees, Beans, and B-Accents. Linguistics and Philosophy 26: 511-545.

Comorovski, Ileana. 1996. Interrogative Phrases and the Syntax-Semantics Interface. Kluwer, Dordrecht.

Cresswell, M. J. and Arnim von Stechow. 1982. De Re Belief Generalized. Linguistics and Philosophy 5: 503-535.

Eckardt, Regine. 2004. Referential and Denotational Topics. Talk given at ZAS, Berlin.

É. Kiss, Katalin. 1991. Logical Structure in Linguistic Structure: The Case of Hungarian. In James Huang and Robert May, eds., Logical Structure and Linguistic Structure. Kluwer, Dordrecht, pp. 387-426.

É. Kiss, Katalin. 2002. The Syntax of Hungarian. Cambridge University Press, Cambridge.

É. Kiss, Katalin and Beáta Gyuris. 2003. Apparent Scope Inversion under the Rise Fall Contour. Acta Linguistica Hungarica 50: 371-404.

von Fintel, Kai. 1994. Restrictions on Quantifier Domains. Ph.D. diss., University of Massachusetts, Amherst.

Frey, Werner. 1993. Syntaktische Bedingungen für die semantische Repräsentation. Studia Grammatica XXXV. Akademie Verlag, Berlin. 
Groenendijk, Jeroen and Martin Stokhof. 1990. Partitioning Logical Space. Annotated handout, Second European Summer School in Logic, Language and Information, Leuven, August 1990.

Gyuris, Beáta. 2002. The Semantics of Contrastive Topics in Hungarian. Ph.D. diss., Eötvös Lodánd University, Budapest.

Gyuris, Beáta. To appear. Ingredients of a Semantic Theory of Contrastive Topics. In Cècile Meier, ed., Proceedings of Sinn und Bedeutung 8.

van Hoof, Hanneke. 2000. The Rise in the Rise-Fall Contour: Does it Evoke a Contrastive Topic or a Contrastive Focus? Ms, Universität Tübingen.

Jacobs, Joachim. 1983. Fokus und Skalen. Zur Syntax und Semantik von Gradpartikeln im Deutschen. Niemeyer, Tübingen.

Jacobs, Joachim. 1997. I-Topikalisierung. Linguistische Berichte 168: 91-133.

Kálmán, László. 1985. Word order in non-neutral sentences. In István Kenesei, ed., Approaches to Hungarian. Volume One: Data and Descriptions. JATE, Szeged, pp. 2537.

Kálmán, László and Ádám Nádasdy. 1994. A hangsúly. [Stress]. In Ferenc Kiefer, ed., Strukturális magyar nyelvtan 2. Fonológia. [A Structural Grammar of Hungarian 2: Phonology]. Akadémiai Kiadó, Budapest, pp. 393-467.

Kálmán, László and Gábor Rádai. 1998. Word Order Variation in Hungarian From a Constructionist Perspective. In Casper de Groot and István Kenesei, eds., Approaches to Hungarian 6: 151-181.

Kenesei, István 1989. Logikus-e a magyar szórend? [Is Hungarian Word Order Logical?] Általános nyelvészeti tanulmányok XVII: 105-152.

Krifka, Manfred. 1991. A Compositional Semantics for Multiple Focus Constructions. In Joachim Jacobs, ed., Informationsstruktur und Grammatik. Linguistische Berichte, Sonderheft 4:17-53.

Krifka, Manfred. 1998. Scope Inversion under the Rise Fall Contour in German. Linguistic Inquiry 29: 75-112.

Krifka, Manfred. 2002. For a Structured Meaning Account of Questions and Answers. In Caroline Féry and Wolfgang Sternefeld, eds., Audiatur Vox Sapientiae. A Festschrift for Arnim von Stechow. Akademie Verlag, Berlin.

Kuno, Susumo. 1982. The Focus of the Question and the Focus of the Answer. CLS 18, Papers from the Parasession on Nondeclaratives. CLS, Chicago.

Lambrecht, Knud. 1994. Information Structure and Sentence Form. Cambridge University Press, Cambridge/New York/Melbourne.

Lee, Chungmin. 1999. Contrastive Topic: A Locus of Interface Evidence from Korean and English. In Ken Turner, ed., The Semantics/Pragmatics Interface from Different Points of View. Elsevier, Oxford.

Molnár, Valéria and Inger Rosengren 1996. Zu Jacobs Explikation der I-Topikalisierung. Sprache und Pragmatik 41: 49-88.

Molnár, Valéria, 1998. Topic in Focus: The Syntax, Phonology, Semantics, and Pragmatics of the so-called Contrastive Topic in Hungarian and German. Acta Linguistic Hungarica 45: 389-466.

Roberts, Craige. 1996. Information Structure in Discourse: Towards an Integrated Formal Theory of Pragmatics. In J. Hak Yoon and Andreas Kathol, eds., Ohio State University Working Papers in Linguistics, vol. 49.

von Stechow, Arnim. 1981. Structured Propositions. Arbeitspapiere des SFB 99. Universität Konstanz.

von Stechow, Arnim. 1991. Focusing and Backgrounding operators. In Werner Abraham, ed., Discourse Particles. John Benjamins, Amsterdam/Philadelphia, pp. 37-84. 
von Stechow, Arnim and Zimmermann, Thomas Ede. 1984. Term Answers and Contextual Change. Linguistics 22: 3-40.

Szabolcsi, Anna 1981a. Compositionality in Focus. Folia Linguistica 15: 141-61.

Szabolcsi, Anna. 1981b. The Semantics of Topic-Focus Articulation. In Jeroen Groenendijk, Theo Janssen and Martin Stokhof, eds., Formal Methods in the Study of Language Part 1. Mathematical Centre Tracts 135. Amsterdam, pp. 1-28.

Szabolcsi, Anna. 1983. Focussing Properties, or the Trap of First Order. Theoretical Linguistics 10: 125-145.

Szabolcsi, Anna and Frans Zwarts. 1993. Weak Islands and Algebraic Semantics. Natural Language Semantics 1: 235-284.

Szabolcsi, Anna. 1997. Strategies for Scope Taking. In Anna Szabolcsi, ed., Ways of Scope Taking. Kluwer, Dordrect, pp. 109-154.

Vallduví, Enric and Elisabet Engdahl. 1996. The Linguistic Realization of Information Packaging. Linguistics 34: 459-519. 